STUDIES IN LITERATURE, CULTURE, AND THE ENVIRONMENT 1

Daniel A. Finch-Race /

Stephanie Posthumus (eds)

\title{
French Ecocriticism
}

From the Early Modern Period to the Twenty-First Century

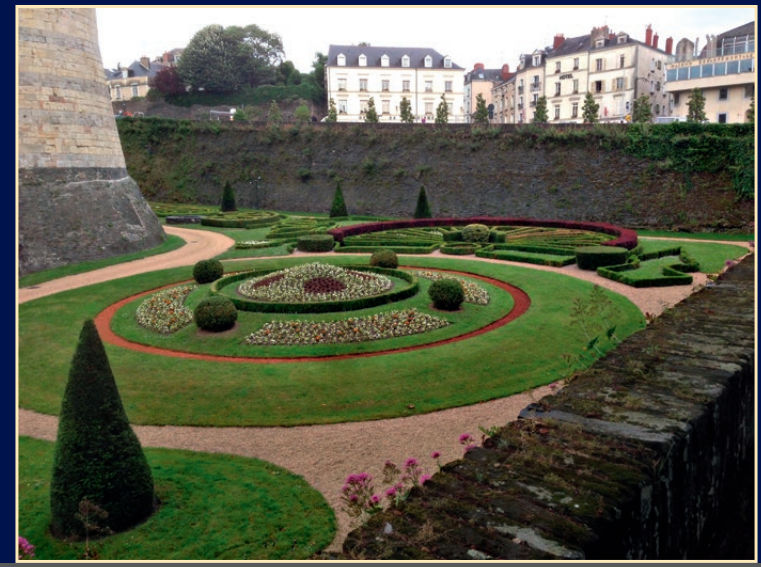


STUDIES IN LITERATURE, CULTURE, AND THE ENVIRONMENT 1

\section{Daniel A. Finch-Race / \\ Stephanie Posthumus (eds) \\ French Ecocriticism}

This book expounds fruitful ways of analysing matters of ecology, environments, nature, and the non-human world in a broad spectrum of material in French. Scholars from Canada, France, Great Britain, Spain, and the United States examine the work of writers and thinkers including Michel de Montaigne, Victor Hugo, Émile Zola, Arthur Rimbaud, Marguerite Yourcenar, Gilbert Simondon, Michel Serres, Michel Houellebecq, and Éric Chevillard. The diverse approaches in the volume signal a common desire to bring together form and content, politics and aesthetics, theory and practice, under the aegis of the environmental humanities.

\section{The Editors}

Daniel Finch-Race is undertaking a Teaching Fellowship at the University of Southampton after completing his $\mathrm{PhD}$ at the University of Cambridge. His primary research entails ecocritical interpretations of nineteenth-century poetry in French and Italian. His publications include a co-edited volume about textures in French contexts, a co-edited issue about ecopoetics in nineteenth-century France, and articles about Baudelaire, Dante, Rimbaud, Tennyson, and Verlaine.

Stephanie Posthumus is Assistant Professor in the Department of Languages, Literatures, and Cultures at McGill University. Working in the field of contemporary French literature, she has published numerous articles on philosophies of nature and ecology, and on representations of landscapes, environments and non-human animals. 
French Ecocriticism 


\section{STUDIES IN LITERATURE, CULTURE, AND THE ENVIRONMENT}

Edited by Hannes Bergthaller, Gabriele Dürbeck, Robert Emmett, Serenella Iovino, Ulrike Plath

\section{Editorial Board:}

Stefania Barca (University of Coimbra, Portugal) Axel Goodbody (University of Bath, UK) Isabel Hoving (Leiden University, The Netherlands) Dolly Jørgensen (Umeå University, Sweden) Timo Maran (University of Tartu, Estonia) Serpil Oppermann (Hacettepe University, Ankara, Turkey)

Dana Phillips (Towson University, Baltimore, USA)

Stephanie Posthumus (McGill University, Montreal, Canada)

Christiane Solte-Gresser (Saarland University, Saarbrücken, Germany)

Keijiro Suga (Meiji University, Tokyo, Japan)

Pasquale Verdicchio (University of California, San Diego, USA)

Berbeli Wanning (University of Siegen, Germany)

Sabine Wilke (University of Washington, Seattle, USA)

Hubert Zapf (University of Augsburg, Germany)

Evi Zemanek (University of Freiburg, Germany)

\section{VOLUME 1}


Daniel A. Finch-Race/Stephanie Posthumus (eds)

\section{French Ecocriticism}

From the Early Modern Period to the Twenty-First Century 
Bibliographic Information published by the Deutsche Nationalbibliothek The Deutsche Nationalbibliothek lists this publication in the Deutsche Nationalbibliografie; detailed bibliographic data is available in the internet at http://dnb.d-nb.de.

\section{Library of Congress Cataloging-in-Publication Data}

A CIP catalog record for this book has been applied for at the Library of Congress.

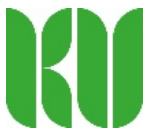

An electronic version of this book is freely available, thanks to the support of libraries working with Knowledge Unlatched. KU is a collaborative initiative designed to make high quality books Open Access for the public good. More information about the initiative and links to the

Open Access version can be found at www.knowledgeunlatched.org

\section{Image Cover:}

Château d'Angers - Moat Garden, @ Stephanie Posthumus

ISSN 2365-645X

ISBN 978-3-631-67345-4 (Print)

E-ISBN 978-3-653-06606-7 (E-PDF)

E-ISBN 978-3-631-71324-2 (EPUB)

E-ISBN 978-3-631-71325-9 (MOBI)

DOI 10.3726/978-3-653-06606-7

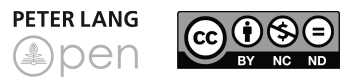

Open Access: This work is licensed under a Creative Commons Attribution Non Commercial No Derivatives 4.0 unported license. To view a copy of this license, visit https://creativecommons.org/licenses/by-nc-nd/4.0/

(C) Daniel A. Finch-Race/Stephanie Posthumus (eds.), 2017

Peter Lang Edition is an Imprint of Peter Lang $\mathrm{GmbH}$.

Peter Lang - Frankfurt am Main · Bern · Bruxelles · New York · Oxford · Warszawa $\cdot$ Wien

This publication has been peer reviewed. www.peterlang.com 


\section{Contents}

Acknowledgements

Daniel A. Finch-Race and Stephanie Posthumus

Introduction: Developing French Ecocriticism 9

\section{Part I Early Modern Economies and Ecologies}

Jeff Persels

Through a Glass Darkly: Dominion and the French Wars of Religion .25

Pauline Goul

The Vanity of Ecology: Expenditure in Montaigne's Vision of the New World.....43

Part II Romanticism and Nature; Naturalism and Animality

Karen F. Quandt

Victor Hugo and the Politics of Ecopoetics 61

Claire Nettleton

Fauves in the Faubourg: Animal Aesthetics in Émile Zola's Thérèse Raquin

\section{Part III Nineteenth-Century Ecopoetics}

Daniel A. Finch-Race

Ecopoetic Adventures in Rimbaud's 'Sensation' and 'Ma Bohème' .99

David E. Evans

Towards an Ecopoetics of French Free Verse:

Marie Krysinska’s Rythmes pittoresques

\section{Part IV Twentieth-Century Ecological Thought}

Teófilo Sanz

Marguerite Yourcenar's Ecological Thinking: Wilderness, Place-Connectedness, Biocentrism, and an Ethic of Care 
Christopher Watkin

Michel Serres: From Restricted to General Ecology

\section{Part V Millennial Bodies, Origins and Becoming-Milieu}

Jonathan Krell

Ecoerotica in Stéphane Audeguy's La Théorie des nuages

175

Nikolaj Lübecker

The Individual as Environment: Watching Jean-Claude Rousseau's

La Vallée close with Lucretius and Simondon

Part VI Twenty-First-Century Natural Limits

Anaïs Boulard

Writing (on) Environmental Catastrophes: The End of the World in Éric Chevillard's Sans l'orang-outan and Michel Houellebecq's

La Possibilité d'une île.

Hannes De Vriese

On the Meaning of Being Alone with Nature: Sylvain Tesson's Ecocritical Sincerity and Ecopoetic Sensuality in Dans les forêts de Sibérie

\section{Part VII Horizons and Prospects}

Stephanie Posthumus

Engaging with Cultural Differences:

The Strange Case of French écocritique

Notes on Contributors

Index. 


\title{
Hannes De Vriese
}

\section{On the Meaning of Being Alone with Nature: Sylvain Tesson's Ecocritical Sincerity and Ecopoetic Sensuality in Dans les forêts de Sibérie}

\begin{abstract}
In the 2011 travelogue Dans les forêts de Sibérie, Sylvain Tesson relates a sixmonth retreat on the banks of Lake Baikal in Siberia. This autobiographical piece of literary nonfiction - motivated by a disgust with Parisian society that is considered to be morose and artificial - celebrates the beauty of pristine nature, and describes the benefits of a humble life in the wilderness. In view of the genre, themes and general configuration of Tesson's text, a filiation with Thoreau's Walden (to which Tesson refers) is obvious, yet there are marked differences in Tesson's narrative: the seasons have little influence on the activities of the narrator, and there is no account of efforts to work the land, or of any engagement with natural cycles. Instead of depicting a vision of independence and harmonious co-existence with nature, the book indulges in hedonic exoticism and sensuality that arise from contact with the wilderness. The ecocritical dimension of Tesson's text centres on the revelation that the narrator's retreat is more of an ecopoetic parenthesis than an ecological utopia. Although Tesson ponders the relations of man towards animals and nature, his experience of the wild - designated as provisional and unstable - is subject to irony and criticism, reflecting what may be a typical French suspicion towards ecological thought, as critics including Alain Suberchicot and Pierre Schoentjes have observed in the works of thinkers (Luc Ferry) and writers (Jean-Christophe Rufin). This chapter broaches the subject of how French literature responds to ecocritical thought and writing that has - until quite recently - been associated with the anglophone world.
\end{abstract}

Key critics of the representation of environmental preoccupations in French literature attest that the North American origins, methods and ideological commitments of ecocriticism have hindered its uptake in France. Pierre Schoentjes notes that 'l'écocritique peine à trouver une place en France. Plusieurs obstacles se présentent [ecocriticism encounters difficulties in finding a place in France. Several obstacles present themselves]'. Schoentjes distinguishes between different causes, some practical - most major works of ecocriticism have not been translated into French - and others that result from deeper cultural and theoretical

1 Pierre Schoentjes, Ce qui a lieu: essai d’écopoétique (Marseille: Wildproject, 2015), 22 [unreferenced translations are mine]. 
divides, particularly from the general suspicion of the French academic world with regard to cultural studies. ${ }^{2}$ Another obstacle to the proliferation of the environmental humanities has been identified by Lawrence Buell, who speaks of critics dismissing ecocriticism due to 'the suspicion that it might not boil down to much more than old-fashioned enthusiasms dressed up in new clothes. ${ }^{3}$ In the field of French literary studies, a critic who undertakes the analysis of nature-writing might be seen as simply replicating studies conducted on, say, landscapes in the work of Julien Gracq (1910-2007), Provençal nature in the writings of Jean Giono (1895-1970), or the Romantic sentiment de nature.

French scholars interested in ecocriticism are confronted with the lack of a clearly defined French corpus. ${ }^{4}$ American literary studies, on the contrary, recognise nature writing as a genre with a prestigious lineage originating with Henry David Thoreau (1817-62), and including several successful contemporary authors such as Barry Lopez (1945-), Gary Snyder (1930-), Annie Dillard (1945-) and Wendell Berry (1934-). ${ }^{5}$ Environmental writing as a genre is largely absent from French publishing, and most major publishers do not offer collections of fiction (or creative non-fiction) about environmental concerns. In 2013, Seuil (Paris, 1935-) founded a new collection, 'Anthropocène', with an environmental scope. ${ }^{6}$ To date, works published in the collection include pieces relating to the humanities and the social sciences, but lacking a literary dimension. Certain publishers, including Wildproject (Marseille, 2009-) and Gallmeister (Paris, 2006-), specialise in environmental fiction, but their catalogues chiefly consist of American authors translated into French.

Recent publications seek to fill this gap in the French critical landscape. An issue of Revue critique de fixxion française contemporaine [Critical Review of Contemporary French Fixxion] from 2015 attests to an increasing interest in environmental questions in contemporary French literature and criticism. In the issue, some critics offer a new approach to well-known authors - Michel Houellebecq;

2 Schoentjes, Ce qui a lieu, 23.

3 Lawrence Buell, The Future of Environmental Criticism: Environmental Crisis and Literary Imagination (Malden, MA: Blackwell, 2005), 2-3.

4 Pierre Schoentjes, 'Texte de la nature et nature du texte: Jean-Loup Trassard et les enjeux de lécopoétique en France', Poétique 164 (2010), 477-94.

5 Alain Suberchicot, Littérature américaine et écologie (Paris: L'Harmattan, 2002); Littérature et environnement: pour une écocritique comparée (Paris: Champion, 2012).

6 Christophe Bonneuil, ed., 'Anthropocène', Seuil (10 October 2013) <http://www.seuil. com/collection/collection-618> [accessed 26 May 2016]. 
Philippe Jaccottet; Michel Deguy ${ }^{7}$ - while others examine the environmental writing of forgotten writers, such as Pierre Gascar. ${ }^{8}$ The majority of the collection deals with a younger generation of writers - Marie-Hélène Lafon; Marie Darrieussecq; Éric Chevillard; Hubert Mingarelli ${ }^{9}$ - in a way that heralds an important place in literary studies for French environmental writing. As I argue in my contribution to the issue,$^{10}$ it is possible that French literary criticism will follow a path similar to American literary criticism ${ }^{11}$ in affording more careful attention to francophone environmental writing.

Despite the fact that an increasing number of French authors reflect upon nature and environments in their work, texts rarely engage in political reflection; French literature thus tends to demonstrate little ecological and political commitment. This could be the result of a certain reluctance within French society, which is arguably mistrustful of political environmentalism. Philosopher and politician Luc Ferry perfectly embodies French scepticism with regard to ecological thought. In Le Nouvel Ordre écologique (1992), Ferry criticises various aspects of environmental ideology, highlighting historical connections between environmentalism and totalitarianism (Nazism; Stalinism). ${ }^{12}$ Throughout the book, Ferry expresses disapproval about certain forms of ecological thought, directing strong criticism towards deep ecology.

7 Emily McLaughlin, 'The Practice of Writing and the Practice of Living: Michel Deguy's and Philippe Jaccottet's Ecopoetics', Revue critique de fixxion française contemporaine 11 (2015), 38-48.

8 Sara Buekens, 'Pour que l'écologie supplante le nationalisme: l'esthétique de Pierre Gascar', Revue critique de fixxion française contemporaine 11 (2015), 49-59.

9 Stephanie Posthumus, 'L'Habiter écologique et l'imaginaire paysan chez Marie-Hélène Lafon et Michel Serres', Revue critique de fixxion française contemporaine 11 (2015), 100-11; Thangam Ravindranathan, 'Un hérisson peut toujours arriver', Revue critique de fixxion française contemporaine 11 (2015), 71-80; Marie Cazaban-Mazerolles, 'La Poétique écologique profonde d'Éric Chevillard', Revue critique de fixxion française contemporaine 11 (2015), 60-70; Sylvie Vignes, 'Hubert Mingarelli: nostalgie et quête d'une eau de source', Revue critique de fixxion française contemporaine 11 (2015), 28-37.

10 Hannes De Vriese, 'Écritures antillaises entre géopoétique et écopoétique: sur la nature des cataclysmes chez Patrick Chamoiseau et Daniel Maximin', Revue critique de fixxion française contemporaine 11 (2015), 16-27.

11 Ursula K. Heise, 'The Hitchhiker's Guide to Ecocriticism', Publications of the Modern Language Association of America 121.2 (2006), 503-16.

12 Luc Ferry, Le Nouvel Ordre écologique: l'arbre, l'animal et l'homme (Paris: Grasset, 1992), 35. 
In the spy novel Le Parfum d'Adam (2011), Jean-Christophe Rufin echoes Ferry's critique of environmentalism, cautioning the reader against ecological terrorism, which is considered as an extreme of deep ecology ${ }^{13}$ Rufin sheds a negative light on environmental activism, which Ferry disdainfully calls 'la nébuleuse écologiste. ${ }^{14}$ In Le Parfum d'Adam, American secret agents work to thwart a group of terrorists planning to eliminate the entire Third World population by spreading a new cholera virus. Utilising the characters and codes of a Hollywood thriller, Rufin shows the dark side of ecologism.

Contemporary French fiction does not roundly condemn environmentalism. Alice Ferney's Le Règne du vivant (2014) offers a fictionalised biography of the environmental activist Paul F. Watson (1950). ${ }^{15}$ Ferney paints a laudatory portrait of Watson's controversial personality in the guise of Magnus Wallace, the central character, who starkly contrasts with Rufin's Ted Harrow, also meant to represent Watson, but in the mode of a dangerous fanatic who acts as a mercenary for the wealthy super-villain Allistair McLeod. By presenting two opposing portraits of Paul Watson, French fiction becomes a forum for debate. Alice Ferney opts to use fiction as a means for expressing political engagement:

Je rends hommage à des militants controversés et je leur donne raison. On reproche aux 'éco-terroristes' d’être dangereux, mais ce sont souvent eux qui sont assassinés. À travers ce livre, je m’engage à leurs côtés.

Je n'ai pas une âme de militante. Dans la vie, je me tais; mais un livre, c'est une voix. Je joue le jeu. ${ }^{16}$

[I honour controversial activists, and I agree with them. 'Eco-terrorists' are criticised for being dangerous, but it is often them who are killed. With this book, I take up their cause.

I do not have the soul of an activist. In life, I keep quiet; a book, however, is a voice. I play the game.]

According to Ferney, the novel is a space for activism. Her position resembles the views of certain Francophone authors: ${ }^{17}$ Patrick Chamoiseau does not hesitate to

13 Jean-Christophe Rufin, Le Parfum d'Adam (Paris: Gallimard, 2011).

14 Ferry, Le Nouvel Ordre écologique, 33.

15 Alice Ferney, Le Règne du vivant (Arles: Actes Sud, 2014).

16 Alice Ferney and Chloé Thibaud, “Je rends hommage aux éco-terroristes”: entretien avec Alice Ferney', BibliObs (20 November 2014), <http://bibliobs.nouvelobs.com/ro mans/20141119.OBS5507/alice-ferney-je-rends-hommage-aux-eco-terroristes.html> [accessed 26 May 2016].

17 Jean-Loup Trassard is different because he outlines his political views in press articles, and reserves fiction for portraits of a rural humanism without an explicit political commitment. Jean-Loup Trassard, 'Arrêtez le massacre', Le 195 (24 February 2016), 
give voice to political, historical and ecological commitments in fiction, ${ }^{18}$ as well as in essays and pamphlets. ${ }^{19}$ Environmental literature is becoming a key genre in contemporary French literature, potentially appealing to a larger readership. ${ }^{20}$

\section{After Walden Pond, Lake Baikal}

Given the increased attention that ecocritical writing and thought is garnering in French literary studies, Sylvain Tesson's travelogue Dans les forêts de Sibérie (2011), relating a six-month retreat on the banks of Lake Baikal in Siberia, is a particularly promising text. Tesson, motivated by disgust with a Parisian society that he considers gloomy and artificial, writes the piece of autobiographical nonfiction to celebrate the beauty of pristine nature, and describe the benefits of a humble life in the wilderness. The genre, themes and general structure of Tesson's text suggest commonality with Thoreau's Walden, and American nature writing more generally. The passage of time has little influence on the activities of the narrator, though, and the author makes no account of working the land or engaging with the cycles of nature (despite the changing seasons structuring the narrative). The book, instead of depicting an ideal of autonomy and a life in harmony with nature, indulges in hedonistic exoticism and sensuality that arises from contact with the wilderness.

The ecocritical dimension of Tesson's text merits scrutiny because the narrator's retreat is less an ecological utopia than an ecopoetic parenthesis. In her contribution to the ecopoetically themed issue of Revue critique de fixxion française contemporaine from 2015, Stephanie Posthumus offers an overview of two modes of analysing representations of nature and environments: ecocriticism adopts an explicitly ecological politics to analyse matters ranging from corporeal issues to toxic landscapes; ${ }^{21}$ ecopoetics emphasises the aesthetic and formal dimensions

$<$ http://le1hebdo.fr/numero/95/arrtez-le-massacre-1469.html> [accessed 26 May 2016]; L'Homme des haies (Paris: Gallimard, 2012).

18 Patrick Chamoiseau, Biblique des derniers gestes: roman (Paris: Gallimard, 2002); Le Papillon et la lumière (Paris: Rey, 2011); L’Empreinte à Crusoé (Paris: Gallimard, 2012).

19 Patrick Chamoiseau and Édouard Glissant, L'Intraitable Beauté du monde: adresse à Barack Obama (Paris: Galaade, 2009)

20 For an observation of a similar trend in British literature, see Jamie Doward, 'Hawks, Butterflies, Coasts And Footpaths: How Nature Writing Turned to Literary Gold', The Guardian (22 March 2015), <https://www.theguardian.com/books/2015/mar/22/ nature-writing-literary-gold $>$ [accessed 26 May 2016].

21 Stacy Alaimo, Bodily Natures: Science, Environment, and the Material Self(Bloomington, IN: Indiana University Press, 2010); Lawrence Buell, 'Toxic Discourse', Critical Inquiry 24.3 (1998), 639-65. 
of literary and artistic representations of nature. ${ }^{22}$ Posthumus rightfully asserts that 'la position de la critique littéraire n'est jamais neutre, jamais désengagée,23 and Tesson's work points to a tension between these two positions that requires further attention.

The incipit to Tesson's novel closely resembles the beginning of Walden, suggesting a debt to the Thoreauvian project:

Je métais promis avant mes quarante ans de vivre en ermite au fond des bois.

Je me suis installé pendant six mois dans une cabane sibérienne sur les rives du lac Baikkal, à la pointe du cap des Cèdres du Nord. Un village à cent vingt kilomètres, pas de voisins, pas de routes d'accès, parfois une visite. L'hiver, des températures de $-30^{\circ} \mathrm{C}$; l'été des ours sur les berges. Bref, le paradis. ${ }^{24}$

[I had promised myself that before turning forty I would live as a hermit in the depths of the woods.

I settled for a six-month period in a Siberian cabin on the shore of Lake Baikal, at the tip of North Cedar Cape. The nearest village is seventy-five miles away, no neighbours, no road access; now and then, a visit. During winter, temperatures below 30 degrees Celsius; during summer, bears on the shores. In a word, paradise.]

Similar reasons are given in the first paragraph of Thoreau's work:

When I wrote the following pages, or rather the bulk of them, I lived alone, in the woods, a mile from any neighbor, in a house which I had built myself, on the shore of Walden Pond, in Concord, Massachusetts, and earned my living by the labor of my hands only. I lived there for two years and two months. At present I am a sojourner in civilized life again. ${ }^{25}$

Both writers begin by explaining how their writing is meant to be an account of their retreat. Before reflecting on the experience, both men identify the geographical terms of their seclusion: Thoreau resides in the woods a little over a mile from the town of Concord; Tesson is miles from any form of civilisation. Akin to Thoreau, Tesson chooses a cabin situated in a landscape composed of trees and water, echoing the desire of the modern man who wishes to escape from society, as Yi-Fu Tuan observes in Topophilia:

22 Nathalie Blanc, Denis Chartier and Thomas Pughe, 'Littérature \& écologie: vers une écopoétique', Écologie \& Politique 36 (2008), 17-28 (21); Daniel A. Finch-Race and Julien Weber, 'Editorial: The Ecocritical Stakes of French Poetry from the Industrial Era', Dix-Neuf 19.3 (2015), 159-66 (161-3).

23 Posthumus, 'L'Habiter écologique', 101.

24 Sylvain Tesson, Dans les forêts de Sibérie: février-juillet 2010 (Paris: Gallimard, 2013), 9 [hereafter $F$ ].

25 Henry D. Thoreau, Walden; or, Life in the Woods (New York, NY: Dover, 1995), 1. 
Today the cabin in the forest clearing remains a powerful lure to the modern man who dreams of withdrawal. Three other natural settings have, at different times and places, appealed strongly to the human imagination. These are the seashore, the valley, and the island. ${ }^{26}$

In the pocket edition of Dans les forêts de Sibérie, the cover image makes another connection with Thoreau's legacy by showing a photograph of the Russian cabin, which is very similar to iconic representations of the cabin in which the American author resided. Tesson's project presents itself as a re-enactment of Thoreau's retreat, but is a more radical experience, as shown by the incipit that emphasises increased remoteness and extreme temperatures. Tesson opts for his retreat from civilised life to be an exotic adventure, whereas Thoreau's project had a more domestic undertone.

The similarities between the sojourn near Walden Pond and the one on Lake Baikal are striking; it seems that Tesson models his retreat and story on the writing of the man considered by many to be the founding father of ecological thought in America. Walden is part of Tesson's 'liste de lectures idéales composée à Paris avec grand soin en prévision d'un séjour de six mois dans la forêt de Sibérie [list of ideal reading material, very carefully drawn up in Paris for the purpose of a six-month stay in the forests of Siberia]' (F 33). In this respect, Dans la forêt de Sibérie appears to be a model of French ecocritical nonfiction.

\section{Out of the world}

Tesson's travels to Russia represent an escape from modern consumer society. A scene in a Russian supermarket at the beginning of the book symbolises the reasons that have led Tesson to leave the civilised world for the Russian wilderness: 'quinze sortes de ketchup. À cause de choses pareilles, j'ai eu envie de quitter ce monde [fifteen kinds of ketchup. Such things have driven me to want to leave this world]' (F 21). The needless variety of the Heinz brand, mentioned twice on the same page, comes to represent the pervasive influence of global consumerism, which extends from great conglomerations such as Paris and New York to the smallest towns of the Russian tundra. Tesson responds to this uncomfortable truth with disgust and disillusion.

Tesson's worldview is a Manichean one, divided between the pristine Siberian wilderness (where events take place over the course of the narration) and landscapes that have been altered and disfigured by human society and industrial

26 Yi-Fu Tuan, Topophilia: A Study of Environmental Perception, Attitudes, and Values (Englewood Cliffs, NJ: Prentice Hall, 1974), 115. 
activity. Throughout the book, Tesson compares and contrasts memories of his urban life with his time on the untouched and lonesome shores of Lake Baikal. The following list enumerates several reasons for his departure:

RAISONS POUR LESQUELLES JE ME SUIS ISOLÉ DANS UNE CABANE

J'étais trop bavard

Je voulais du silence

Trop de courrier en retard et trop de gens à voir

J'étais jaloux de Robinson

C'est mieux chauffé que chez moi,

à Paris

Par lassitude d'avoir à faire les courses

Pour pouvoir hurler et vivre nu

Par détestation du téléphone

et du bruit des moteurs. (F 118)

[REASONS FOR WHICH I HAVE ISOLATED MYSELF IN A CABIN

I was too talkative;

I wanted silence;

Too much late mail and too much people to see;

I was jealous of Robinson;

It's better heated here than at my place

in Paris;

I was tired of having to shop;

In order to be able to yell and live naked;

Because I hate the telephone

and the noise of engines.]

The author describes his feelings of disgust and alienation when he was in the city. He not only needs to flee consumerist profligacy, but also superficial social niceties, noise and pollution. The civilised world is associated with degradation and decay.

Tesson aligns himself with Arne Næss's thesis that overpopulation is a major strain on the earth's ecosystem. In Le Nouvel Ordre écologique, Ferry passionately criticises the position of the father of deep ecology, which he considers to be a form of anti-humanism. ${ }^{27}$ Likewise, Rufin highlights the possible abuses of ecological Malthusianism. ${ }^{28}$ Tesson, on the contrary, takes the side of deep ecology, not by referring directly to Arne Næss, but by quoting the speech made by Claude

27 Ferry, Le Nouvel Ordre écologique, 157.

28 Rufin, Le Parfum d'Adam, 407. 
Lévi-Strauss upon receiving the Premi Internacional Catalunya in $2005 .{ }^{29}$ The problem of human demographical growth surfaces when Igor, a Russian friend of Tesson, confides his distress because he and his wife cannot conceive. The narrator considers fertility problems to be an advantage from an ecological viewpoint:

Je n'ose le consoler en lui disant que la termitière humaine est pleine à craquer. Que Claude Lévi-Strauss désignait comme des 'vers à farine' les milliards d'humains entassés sur une sphère trop étroite et constatait que nous étions en train de nous intoxiquer. Que le vieux maitre, inquiet de voir la pression démographique mettre la Terre sous tension, 's'interdisait toute prédiction sur l'avenir', lui qui était né dans un monde six fois moins peuplé. (F 233-4)

[I do not dare to comfort him by saying that the human termite mound is more than full, that Claude Lévi-Strauss used the term 'mealworms' for the billions of humans crowded together on a too narrow sphere, or that he noted how we are poisoning ourselves. Nor dare I say that the old master, worried when observing how demographic pressure has become a strain for the Earth, 'forbade himself to make any prediction for the future'; he who was born in a world six times less populated.]

In line with Lévi-Strauss, Tesson's pessimistic worldview - the globe is overpopulated and on the edge of environmental collapse - suggests that bearing children is not a good idea.

Portraying the planet as a sort of human termite mound not only leads to practical considerations about food supply and waste production, but also induces an aesthetic malaise, at which Tesson hints in the passage about his disgust regarding Heinz ketchup. It is the proliferation of human beings that contributes to the expansion of bad taste:

La ruée des peuples vers le laid fut le principal phénomène de la mondialisation. Pour s'en convaincre il suffit de circuler dans une ville chinoise, d'observer les nouveaux codes de décoration de La Poste française ou la tenue des touristes. Le mauvais goût est le dénominateur commun de l'humanité. (F 29)

[The rush of the masses toward ugliness was the main characteristic of globalisation. It becomes evident when moving through a Chinese city, when observing the new design code in French postal offices, or tourists' clothing. Bad taste is humanity's common denominator.]

If globalisation and its tendency to standardise the tastes of the masses offend the author's aesthetic sensibilities, Tesson is doing no more than restating the kind of

29 Claude Lévi-Strauss, 'L'Etnòleg enfront de les identitats nacionals', Generalitat de Catalunya (30 March 2005), <http://web.gencat.cat/web/.content/03_GENERALITAT/PIC/ documents/pdf/discurs_levi_strauss.pdf> [accessed 27 May 2016]. 
dissatisfaction with industrialisation that can be found in the work of David H. R. Lawrence (1885-1930). After reading Lady Chatterley's Lover (1928), the narrator criticises industrial (and post-industrial) societies that, because of their obsession with progress, lose something vital: 'c'est l'agonie du monde. "L'Angleterre industrielle efface l'Angleterre agricole". Constance sent une sève monter dans sa chair; elle comprend que le progrès désubstantialise le monde [the world is in agony. "Industrial England blots out agrarian England". Constance feels lifeblood running through her veins; she understands that progress alters the world's substance]' ( $F$ 121). Tesson yearns for a place where he can be true to himself, and free from society. He wants to express his disenchantment with contemporary society, and rediscover the essence of the world, away from landscapes disfigured by mankind.

Only the empty mountain landscapes of Lake Baikal allow Tesson to reconnect with what can be considered the cosmic order of the world. He proposes to divide global space into two narrow categories - inhabited or untouched:

Ces montagnes n'offrent rien qu'une profusion de sensations à éprouver sur-le-champ. L'homme ne les bonifiera jamais. Dans ce paysage sans promesse, écartelé de grandeur, les calculateurs en seront pour leurs frais. [...] Aménageur, passe ton chemin, regagne la Toscane! Là-bas, sous les ciels tempérés, les paysages attendaient que l'homme les façonne en campagne. Ici, dans cet amphithéâtre, les éléments règnent pour l'éternité. Il y eut des luttes dans les temps magmatiques, à présent, le calme. Le paysage, repos de la géologie. (F 282)

[These mountains offer nothing but an abundance of sensations to be felt in the moment. Man will never improve them. In this landscape without promises, wide open with magnificence, every plot or plan is defeated. [...] Move on, developer, return to Tuscany! There, under temperate skies, landscapes wait to be moulded by mankind. Here, in this amphitheatre, the elements reign for eternity. There were struggles in magmatic times; at present, calmness. The landscape is geology's rest.]

As far as Tesson is concerned, even beautifully shaped bucolic landscapes are to be considered part of modern society's wrongdoings. He does not admire Tuscan landscapes, entirely developed by man, and seeks pristine landscapes that contain the possibility of a mystic experience of nature.

\section{Wilderness and transcendence}

Having the potential to provide a mystic experience is the basis of another opposition between Paris and Lake Baikal: the civilised world is profane; the wilderness holds the possibility of transcendence. Tesson writes: ‘j’ai quitté le caveau des villes et vécu six mois dans l'église des taïgas [I left the urban vaults and lived for six months in the church of the taiga]' (F 228). By transforming the Russian mountains into a church, Tesson thinks of nature and landscape in religious terms. 
Tesson's preoccupations go beyond the practical considerations of pollution, social obligations, and the lack of good taste of the masses. He engages with a more spiritual way of thinking about nature, which is, as John Gatta explains, a fundamental feature of contemporary environmental thinking:

The current ecological crisis must be understood, I think, not as an array of technical problems but as a genuine crisis of spirit and imagination. Since religion deals in ultimate questions, while our culture's literature embodies its deepest hopes and fears, an interfusion of both disciplines should cast light on this major issue of our time. ${ }^{30}$

According to Gatta, the search for transcendence in nature writing reveals the complexity of the environmental crisis, which is more spiritual than it may appear. Religious motifs in Tesson's book echo this idea.

Gatta observes that American nature writing - his main object of study maintains a strong interest in the sanctity of wilderness, even though completely untouched landscapes have become extremely rare. This is even more true in a European context. In Recours à la 'nature sauvage' (2007), Robert Hainard cites comparable examples of unspoilt landscapes in Europe - the list is extremely short:

La Suisse possède encore quelques hectares de forêt vierge, mais je les connais surtout en Yougoslavie. Ce sont des forêts de montagne, évidemment. Elles sont de parcours faciles, mais toujours dans des endroits difficiles et vallonnés. Je connais aussi celle de Białowieża en Pologne. En France on trouve des forêts de fayards dans le Massif central, et quelques forêts très sauvages dans les Pyrénées, comme celle du Soussouéou en haute vallée d'Ossau. ${ }^{31}$

[In Switzerland, a few hectares of virgin forest subsist, but I know more of such things in Yugoslavia. They are mountain forests, obviously. They encompass easy routes, but always situated in difficult and hilly terrain. I also know the forest of Białowieża in Poland. In France, there are beech forests in the Massif Central, and some very wild forests in the Pyrenees, such as the Soussouéouan forest in the upper Ossau Valley.]

An avid alpinist, Tesson well knows how rare untouched nature is in Europe. As an author living in western Europe, it is necessary for him to travel in order to encounter natural landscapes that are not embedded, as a sort of shrine, within civilised territory. A key trait of nineteenth-century nature writing, this fascination with the 'wild' continues to influence contemporary authors. Despite the rareness of untamed landscapes - perhaps because of it - writers assign sacred value to the wilderness. As Gatta explains:

30 John Gatta, Making Nature Sacred: Literature, Religion, and Environment in America from the Puritans to the Present (Oxford: Oxford University Press, 2004), viii.

31 Robert Hainard, Recours à la 'nature sauvage' (Bats: Utovie, 2007), 36-9. 
Although virtually nothing we encounter on the planet can now be regarded as outside the sphere of human influence, one can at least identify organisms and processes that seem relatively 'wild' - that is, beyond immediate human control. The sacred, too, traditionally names a reality apart from workaday culture, a category of existence outside the bounds of human control and rationalization. ${ }^{32}$

Tesson experiences transcendence only in the forests around Lake Baikal; he thus reproduces a traditional trope that is part of the heritage of American nature writing.

The travelogue is marked from the beginning by a transcendental desire. Tesson starts the novel by staging the journey to the lake as the inauguration of a lifealtering experience: going to Lake Baikal means 'changer de vie [changing life]' (F 22). The author drives over the frozen lake in order to arrive at the cabin - a dangerous and impressive feat that resembles a ritual of initiation:

Rouler sur un lac est une transgression. Seuls les dieux et les araignées marchent sur les eaux. J'ai ressenti trois fois l'impression de briser un tabou. La première, en contemplant le fond de la mer d'Aral. La seconde en lisant le journal intime d'une femme. La troisième, en roulant sur les eaux du Baïkal. Chaque fois, l'impression de déchirer un voile. L'œil regarde par le trou de la serrure.

J'explique cela à Micha. Il ne répond rien. (F 24)

[To drive on a lake is a transgression. Only gods and spiders walk on water. Three times, I had the impression of breaking a taboo. First, when contemplating the bed of the Aral Sea. Second, when reading a women's diary. Third, when driving on the waters of Lake Baikal. Each time, I had the impression of ripping a veil, of looking through a keyhole.

I explain this to Micha. He does not answer.]

Whilst going across the lake, Tesson is under the impression that he is usurping a privilege of the gods. He considers his action to be a transgression, a means to unveil a truth - another dimension of reality that should not be known to man. His companion Micha remains silent, underscoring the momentousness of the event.

From then on, the sojourn on the lake's shores is considered a religious retreat; it pleases Tesson to think of himself as a kind of religious hermit. He associates his disgust regarding city life with the horror mundi of the Desert Fathers of early Christianity:

$\mathrm{Au} \mathrm{IV}{ }^{\mathrm{e}}$ siècle, les Pères du désert devenaient fous de solitude: ils ne supportaient plus la moindre intrusion. Ils refluaient au fond des déserts, s'enfouissaient dans les grottes. Leurs réserves d'amour se vouaient à un monde vide de leurs semblables. Dans les banlieues, parfois, un type tire une volée de plombs dans un groupe de jeunes, au pied d'une tour. Il finit en entrefilet dans Le Parisien, puis derrière les barreaux. (F 45-6)

32 Gatta, Making Nature Sacred, 9. 
[In the fourth century, the Desert Fathers became obsessed with loneliness: they could no longer withstand the slightest intrusion. They withdrew far into the desert, and confined themselves in caverns. Their reserves of love were vowed to a world lacking their kin. From time to time, a guy in the suburbs shoots at a group of youngsters in front of a housing building. He ends up being briefly mentioned in Le Parsien [The Parisian], then in jail.]

The stress and the discomfort of living in a crowded society lead to a coup de folie - a resentful act of madness such as murder. For Tesson, seclusion brings peace, understanding and spiritual fulfilment.

Tesson's retreat is, however, an extremely fragile endeavour, easily disturbed by the slightest sign of human activity. When fishermen playing loud music pass nearby, the religious motif emerges again, as the narrator takes the integrity of his retreat to have been undermined. He compares his situation to the experience of monks forced to guide tourists around a place that is supposed to be a haven of calm and serenity:

Ce que je suis venu fuir s'abat sur mon îlot: le bruit, la laideur, la grégarité testostéronique. [...] Je pense à ces reclus bénédictins contraints de guider les visites touristiques - ces religieux venus enfermer leur foi dans des cloîtres se retrouvent à détailler la règle de saint Benoît à des foules indifférentes. (F 45-6)

[What I have been hiding from invades my island: noise, ugliness, testosteronic gregariousness. [...] I think of those Benedictine recluses who are forced to guide tourists those monks who intended to seal their faith in cloisters end up explaining the Rule of Saint Benedict to unconcerned crowds.]

Religious imagery recurs throughout the book: the stove that heats the cabin is compared to a small divinity - 'un petit dieu qui possède sa vie propre [a small god possessed of its own life]' ( $F$ 37) - that claims logs as offerings; an ornithological guidebook published by Delachaux \& Niestlé becomes 'un bréviaire consacré à l'ingéniosité du vivant, aux infinies subtilités de l'évolution, une célébration du style [a breviary dedicated to the inventiveness of all that lives, to the infinite nuances of evolution; a celebration of style]' (F 215), giving credence to the idea of a 'nature bible'.

\section{Disenchantments}

Tesson's work shares several traits with environmental nonfiction - recurring reflections on the transcendent nature of beauty; denunciations of consumer society and its impact on the environment; a literary rendering of real events - but his ecological and literary project is substantially problematic. According to Schoentjes, Tesson's work is a site of tensions because it expresses political commitment and disengaged contemplation: 
La tension qui s'observe chez Tesson entre un engagement militant en faveur de l'environnement et la volonté de s'inscrire dans une écriture de la sagesse inspirée par la contemplation de la nature est caractéristique. ${ }^{33}$

[In Tesson's work, one finds a characteristic tension between political commitment in favour of the environment, and the desire to comply with a form of literature that seeks wisdom by contemplating nature.]

Schoentjes explains that such contradictions arise because a solitary experience of nature, entailing detachment from any collective responsibility, runs counter to ecological commitment. Tesson does not eschew such inconsistencies; they are a key part of the story's development.

Many of the contradictions of Tesson's ecological project are underscored in the text. When evoking the magic beauty of the lake and the surrounding wild forest, he deconstructs this magic by considering the minimal impact of the panorama on others, especially the Russian inhabitants who have lived there for years:

J'aurai appris qu'on peut vivre près d'une patinoire géante, se nourrir de caviar, de pattes d'ours et de foie d'élan, se vêtir de vison, aller par les futaies fusil en bandoulière, assister chaque matin, lorsque les rayons de l'aube touchent la glace, à l'un des plus beaux spectacles de la planète, et rêver pourtant d'une vie dans un appartement équipé de toute la robotique et de la gadgeterie high-tech. (F 158)

[I will have learned that one can live next to an enormous ice rink, feed on caviar, bear paws and moose liver, clothe oneself in mink, walk beneath the trees with a rifle over one's shoulder, bear witness every morning to one of the most beautiful sights on the planet when the first rays of sunlight strike the ice, and nevertheless dream of living in an apartment equipped with robotics and high-tech gadgets.]

The locals do not share Tesson's enthusiasm for the magnificent view, and his wonder eventually begins to diminish: 'les rives du Baikal me sont à présent trop familières pour me tirer la moindre larme [at present, the banks of Lake Baikal are too familiar to make me shed a tear]' (F 228). As time passes, the adventurer's enthusiasm dries up - the pristine beauty of the scenery no longer moves him.

Tesson's story of adventure and ecological consciousness entails elements of disillusionment. When the author uses mystic and religious references to describe his experience, there is the risk that such description may tip into irony. When he compares the lake to 'une patinoire géante [a giant ice rink]', Tesson attenuates the possible sacredness of the site. The sublime, when glimpsed, is always subject to doubt. Religious language tends to be used to designate trivial objects: Tesson, who loves cigars, compares cigar-smoke to incense ( $F$ 178). When visitors or

33 Schoentjes, Ce qui a lieu, 166. 
Russian friends explain their spiritual worldview, Tesson is only able to stomach such 'bouillie spirituelle [spiritual 'nonsense]' because of his childhood religious education: 'un vieux résidu de patience inoculée par dix années d'éducation chez les frères m'aide à supporter la bouillie spirituelle [some residual patience acquired through a ten-year education provided by the brothers helps me to bear this spiritual nonsense]' ( $F$ 284). As a result of such a religious background, spirituality is kept at an ironic distance.

The multiple discrepancies and dissonances in the text indicate the flaws and contradictions of the author's project. Tesson notes, with a degree of self-derision, that the solitary nature of his endeavour is problematic: 'de mon duvet, jentends crépiter le bois. Rien ne vaut la solitude. Pour être parfaitement heureux, il me manque quelqu'un à qui l'expliquer [from under my duvet, I hear the firewood crackle. Nothing equates to solitude. In order to be perfectly happy, I would simply need someone to whom I can explain this]' ( F 160). The lonely retreat in the woods veers dangerously close to disappointment. The project is significantly compromised from the early moment in which Tesson buys large quantities of Heinz ketchup despite being disgusted by the mere presence of the brand in a small Russian town. The Thoreauvian dream of autarchy is jeopardised: Tesson never achieves independence, lives on industrial food (dried pasta, ketchup) brought with him rather than cultivating vegetables, and fails to leave behind modern technology (his laptop and satellite phone).

The retreat appears to be less serious and sincere than Thoreau's undertaking. Tesson's incipit expresses his intention more as a personal challenge than a necessity - the project is based on a vow to live as a hermit in the woods before reaching his fortieth birthday ( $F 9)$. The solitary adventure seems rather shallow, as do the author's motivations when settling into his cabin. Tesson is inconvenienced by the bad taste of the masses, and shocked by the Russians' poor sense of interior design. Upon his arrival, the author breaks down Formica panels, tears off linoleum surfaces, and throws out all plastic materials (F 29). He aims to reveal the cabin's woodwork, coated in materials manufactured by the petrochemical industry, but this moment of redecorating or 'home-making' feels more like a bourgeois reflex, transforming the experience into a privilege afforded to an elite few that David Brooks describes as 'bourgeois bohemians. ${ }^{34}$

34 David Brooks, Bobos in Paradise: The New Upper Class and How They Got There (New York, NY: Simon \& Schuster, 2000), 11. 


\section{Between ecological commitment and ecopoetic aesthetics}

As an attempt at ecological commitment, Tesson's project appears to be a failure in many respects. Such a sentiment is expressed by the author:

Le courage serait de regarder les choses en face [...]. La nostalgie, la mélancolie, la rêverie donnent aux âmes romantiques l'illusion d'une échappée vertueuse. Elles passent pour d'esthétiques moyens de résistance à la laideur mais ne sont que le cache-sexe de la lâcheté. Que suis-je? Un pleutre, affolé par le monde, reclus dans une cabane, au fond des bois. Un couard qui s'alcoolise en silence pour ne pas risquer d'assister au spectacle de son temps ni de croiser sa conscience faisant les cent pas sur la grève. ( $F$ 196)

[It would be more courageous to face the truth [...]. Nostalgia, melancholia and reverie - which fill Romantic souls with the illusion of a virtuous escape - are considered to be aesthetic ways of resisting ugliness, but they are only a loincloth for cowardice. Who am I? A wimp, made distraught by the world, shut away in a cabin in the depths of the woods. A coward who gets drunk in silence because he does not want to risk witnessing the spectacle of his era, or come across his own conscience while pacing on the shore.]

Tesson, blaming himself for ecological shallowness and Romantic escapism, considers his adventure to be an act of cowardliness. Yet, if Dans les forêts de Sibérie appears to be a watered-down version of Thoreau's retreat, Tesson's doubts and ironic self-awareness correlate well with Thoreau's 'protopostmodern sensibility', as explained by David Dowling:

The very essence of the natural process in Thoreau's writing [...] bears a distinctly protopostmodern sensibility, from self-referential pastiche to ecstatic, soaring visionary reveries that crash on the rocks of his neighbors' galling capitalist exploitation of the environment. A sense of optimism always edges against the bizarre, even surreal, effects economic sins that reify the environment as property and raids its resources of timber, ice, and fur to feed an insatiable demand of consumer goods. ${ }^{35}$

Regardless of whether Tesson succeeds in experiencing an ecological adventure, his travelogue calls into question modern consumer societies. Tesson's self-derision serves as a mirror for his readers, and he develops an ecologically committed perspective in spite of his own scepticism. For Tesson, being alone with nature is a problematic ecological project: his retreat was temporary, and his actions in favour of the environment seem ineffective. Hedonistic and aesthetic pleasures are more effective: 'je ne sais pas si la beauté sauvera le monde. Elle a sauvé ma soirée

35 David Dowling, 'Fraught Ecstasy: Contemporary Encounters with Thoreau's Postpristine Nature, in Thoreauvian Modernities: Transatlantic Conversation on an American Icon, ed. by F. Specq, L. D. Walls and M. Granger (Athens, GA: University of Georgia Press, 2013), 234-48 (236). 
[I do not know if beauty will save the world, but it has saved my evening]' (F 50). Tesson is subject to doubt and melancholy, which he can only capture by describing 'l'intensité esthétique [the aesthetic intensity]' ( $F$ 214) of nature's display. By writing about the woods, recounting the choreography of butterflies, and remembering the 'ecological sublime ${ }^{36}$ of the mountain views, Tesson produces a work of ecopoetics (in the sense that French literary criticism has given to the term). ${ }^{37}$

Dans les forêts de Sibérie oscillates between an ecopoetic sense of nature's fragile beauty, and an ecological endeavour that is deemed to have failed. This is true of many French literary projects: like Tesson, who chooses to undermine the ecocritical effectiveness of his undertaking, Trassard seeks to separate ecological commitment from fiction. The tension between ecocriticism and ecopoetics is a defining characteristic of contemporary scholarship and thought. Working with different traditions of literary criticism is a productive way of discerning important aspects of environmental writing in French.

\section{References}

Alaimo, Stacy, Bodily Natures: Science, Environment, and the Material Self(Bloomington, IN: Indiana University Press, 2010)

Blanc, Nathalie, Denis Chartier and Thomas Pughe, 'Littérature \& écologie: vers une écopoétique', Écologie \& Politique 36 (2008), 17-28

Bonneuil, Christophe, ed., 'Anthropocène', Seuil (10 October 2013) <http://www. seuil.com/collection/collection-618> [accessed 26 May 2016]

Brooks, David, Bobos in Paradise: The New Upper Class and How They Got There (New York, NY: Simon \& Schuster, 2000)

Buekens, Sara, 'Pour que l'écologie supplante le nationalisme: l'esthétique de Pierre Gascar', Revue critique de fixxion française contemporaine 11 (2015), 49-59

Buell, Lawrence, The Future of Environmental Criticism: Environmental Crisis and Literary Imagination (Malden, MA: Blackwell, 2005)

—, 'Toxic Discourse', Critical Inquiry 24.3 (1998), 639-65

Cazaban-Mazerolles, Marie, 'La Poétique écologique profonde d'Éric Chevillard', Revue critique de fixxion française contemporaine 11 (2015), 60-70

Chamoiseau, Patrick, Biblique des derniers gestes: roman (Paris: Gallimard, 2002)

36 Christopher Hitt, 'Toward an Ecological Sublime', New Literary History 30.3 (1999), 603-23 (607).

37 Blanc, Chartier and Pughe, 'Littérature \& écologie',21; Finch-Race and Weber, 'Editorial', 161-3; Posthumus, 'L’Habiter écologique', 101. 
—, L'Empreinte à Crusoé (Paris: Gallimard, 2012)

-, Le Papillon et la lumière (Paris: Rey, 2011)

—, and Édouard Glissant, L'Intraitable Beauté du monde: adresse à Barack Obama (Paris: Galaade, 2009)

De Vriese, Hannes, 'Écritures antillaises entre géopoétique et écopoétique: sur la nature des cataclysmes chez Patrick Chamoiseau et Daniel Maximin', Revue critique de fixxion française contemporaine 11 (2015), 16-27

Doward, Jamie, 'Hawks, Butterflies, Coasts And Footpaths: How Nature Writing Turned to Literary Gold', The Guardian (22 March 2015), <https://www.the guardian.com/books/2015/mar/22/nature-writing-literary-gold $>$ [accessed 26 May 2016]

Dowling, David, 'Fraught Ecstasy: Contemporary Encounters with Thoreau's Postpristine Nature', in Thoreauvian Modernities: Transatlantic Conversation on an American Icon, ed. by F. Specq, L. D. Walls and M. Granger (Athens, GA: University of Georgia Press, 2013), 234-48

Ferney, Alice, Le Règne du vivant (Arles: Actes Sud, 2014)

-, and Chloé Thibaud, “Je rends hommage aux éco-terroristes”: entretien avec Alice Ferney', BibliObs (20 November 2014), <http://bibliobs.nouvelobs.com/ romans/20141119.OBS5507/alice-ferney-je-rends-hommage-aux-eco-terror istes.html> [accessed 26 May 2016]

Ferry, Luc, Le Nouvel Ordre écologique: l'arbre, l'animal et l'homme (Paris: Grasset, 1992)

Finch-Race, Daniel A., and Julien Weber, 'Editorial: The Ecocritical Stakes of French Poetry from the Industrial Era', Dix-Neuf 19.3 (2015), 159-66

Gatta, John, Making Nature Sacred: Literature, Religion, and Environment in America from the Puritans to the Present (Oxford: Oxford University Press, 2004)

Hainard, Robert, Recours à la 'nature sauvage' (Bats: Utovie, 2007)

Heise, Ursula K., 'The Hitchhiker's Guide to Ecocriticism', Publications of the Modern Language Association of America 121.2 (2006), 503-16

Hitt, Christopher, 'Toward an Ecological Sublime', New Literary History 30.3 (1999), 603-23

Lévi-Strauss, Claude, 'L'Etnòleg enfront de les identitats nacionals', Generalitat de Catalunya (30 March 2005), <http://web.gencat.cat/web/.content/03_GEN ERALITAT/PIC/documents/pdf/discurs_levi_strauss.pdf> [accessed 27 May 2016]

McLaughlin, Emily, 'The Practice of Writing and the Practice of Living: Michel Deguy's and Philippe Jaccottet's Ecopoetics', Revue critique de fixxion française contemporaine 11 (2015), 38-48 
Posthumus, Stephanie, 'L'Habiter écologique et l'imaginaire paysan chez MarieHélène Lafon et Michel Serres', Revue critique de fixxion française contemporaine 11 (2015), 100-11

Ravindranathan, Thangam, 'Un hérisson peut toujours arriver', Revue critique de fixxion française contemporaine 11 (2015), 71-80

Rufin, Jean-Christophe, Le Parfum d'Adam (Paris: Gallimard, 2011)

Schoentjes, Pierre, Ce qui a lieu: essai décopoétique (Marseille: Wildproject, 2015)

-, 'Texte de la nature et nature du texte: Jean-Loup Trassard et les enjeux de l'écopoétique en France', Poétique 164 (2010), 477-94

Suberchicot, Alain, Littérature américaine et écologie (Paris: L'Harmattan, 2002)

-, Littérature et environnement: pour une écocritique comparée (Paris: Champion, 2012)

Tesson, Sylvain, Dans les forêts de Sibérie: février-juillet 2010 (Paris: Gallimard, 2013)

Thoreau, Henry D., Walden; or, Life in the Woods (New York, NY: Dover, 1995)

Trassard, Jean-Loup, 'Arrêtez le massacre', Le 195 (24 February 2016), <http://le 1hebdo.fr/numero/95/arrtez-le-massacre-1469.html> [accessed 26 May 2016]

—, L'Homme des haies (Paris: Gallimard, 2012)

Tuan, Yi-Fu, Yi-Fu Tuan, Topophilia: A Study of Environmental Perception, Attitudes, and Values (Englewood Cliffs, NJ: Prentice Hall, 1974)

Vignes, Sylvie, 'Hubert Mingarelli: nostalgie et quête d'une eau de source', Revue critique de fixxion française contemporaine 11 (2015), 28-37 



\section{Index}

A

Abercromby, Ralph

Seas and Skies in Many Latitudes $178 \mathrm{n} 7$

Aberth, John

An Environmental History of the Middle Ages 26n2

Abraham, Luc

'Un entretien avec Michel Serres' [with Serres, Michel] see Serres, Michel

Abu-Lughod, Lila

'Writing Against Culture' 259

Alaimo, Stacy

Bodily Natures 235n21

Allamand, Carole

'Du sommaire au moindre' 224n20

Aloi, Giovanni

Art \& Animals 90

Apollinaire, Guillaume

Alcools 118

Arbel, Benjamin

'The Renaissance Transformation of Animal Meaning' 15

Aristotle 47,49

Poetics 10n1

ASLE [Association for the Study of

Literature and Environment] 11, 216

ASLE-UKI [Association for the Study of Literature and Environment in the United Kingdom and Ireland] 11

Atahualpa 49

Atwood, Margaret

MaddAddam 217

Audeguy, Stéphane
'De la nature de quelques choses' 178-9, 191

La Théorie des nuages 176-80, $182-5,186,187,188,189,190$, 191-2

Opera mundi 184-6, 187, 191

B

Bacon, Francis 86, 91-2

Balzac, Honoré de 85

Banville, Théodore de

Les Stalactites 128

Barjavel, René

Ravage 218

Barnaud, Nicolas

Le Cabinet du roy de France 32-4, $36,37,39$

Barrère, Jean-Bertrand

La Fantaisie de Victor Hugo 63, $68 \mathrm{n} 28$

Bartosch, Roman

'The Function of Criticism' [with Garrard, Greg] 133

Bass, Rick 261

Bataille, Georges 44

La Part maudite; La Notion de dépense [ed. by Piel, Jean] 52-3, 55

Bate, Jonathan

The Song of the Earth 26, 39, 75-6, 141

Baudelaire, Charles

Les Fleurs du mal 120, 186-7

Beauvoir, Simone de

Le Deuxième Sexe 145

Bellenger, Yvonne

"Nature" et "Naturel" dans quatre chapitres des Essais' 46n10 
Benedict, Saint [Benoît, saint] 243

Bennett, Jane

'De Rerum Natura' 206

Bentham, Jeremy 146

Bergson, Henri

Extraits de Lucrèce 200-3, 208, 210

Bergthaller, Hannes

'The Canon of East Asian Ecocriticism and the Duplicity of Culture' 19

Bernard, Claude

Introduction à létude de la médecine expérimentale 85

Berry, Wendell 232

Beuve-Méry, Alain

'Stéphane Audeguy' 190

Bible

Adam and Eve 164

Genesis 28

Genesis '1.28’ 29

God 29

Leviticus '26.3-6' [King James version] 38

Leviticus '26.3-6' [trans. by Olivétan, Pierre Robert] 38

Noah 28

Song of Solomon 187

Song of Solomon '7.2-3' 188

Song of Solomon '7.7' 188

Biogea 149

Blanc, Nathalie

Les Formes de l'environnement 216n4

'Littérature \& écologie' [with Chartier, Denis; Pughe, Thomas] 11n6, 61, 190, 236n22, 247n37, 263

Bodin, Jean

Les Six Livres de la République 30, 36n 29
Boehrer, Bruce T.

Environmental Degradation in Jacobean Drama 26n2

Bonnefoy, Yves

Hier régnant désert 15

Bonneuil, Christophe 'Anthropocène' 232n6

Bordage, Pierre 218n11

Bosch, Hieronymus 72

Boudreau, Douglas

Ecocritical Approaches to Literature in French [with Sullivan, Marnie] 10

Boulle, Pierre 218n11

Boutros-Ghali, Boutros 168-9

Bouvet, Rachel

'Eco- and Geo- Approaches in

French and Francophone Literary Studies' [with Posthumus, Stephanie] 262

Boyle, Claire

'Post-Queer (Un)Made in France?' 260n 26

Breton, André 145

Les Champs magnétiques [with Soupault, Philippe] 14-15

Brombert, Victor

Victor Hugo and the Visionary

Novel $74 \mathrm{n} 33$

Brooks, David

Bobos in Paradise 245

Brooks, Peter

Body Work 183n24, 184

Brunel, Pierre

Rimbaud 105-6, 107

Brunhes, Jean

Leçons de géographie 200,202, 207

Bryson, J. Scott

The West Side of Any Mountain 100, 103-4 
Buekens, Sara

'Pour que l'écologie supplante le nationalisme' $233 \mathrm{n} 8$

Buell, Lawrence

'Ecocriticism' 216

The Environmental Imagination $10 \mathrm{n} 1,263,265 \mathrm{n} 46$

The Future of Environmental Criticism 66n21, 72n31, 83, 232

'Toxic Discourse' 235n21

Writing for an Endangered World 141n11, 190

Bureau, Luc

Terra erotica 175, 176, 187-9, 191

C

Caillois, Roger 148

Carson, Rachel

Silent Spring 143

Cazaban-Mazerolles, Marie

'La Poétique écologique profonde d'Éric Chevillard' 233n9

Célestin, Roger

'Editors' Introduction' [with DalMolin, Eliane; Dambre, Marc; Golsan, Richard J.] 257

Centre International de Documentation Marguerite Yourcenar

Bulletin du Centre International de Documentation Marguerite Yourcenar 138

Cerquiglini, Blanche

'Éric Chevillard' [with Chevillard, Éric] 227n27

Certeau, Michel de 264

Cézanne, Paul 85, 90-1

Chamoiseau, Patrick 234-5

Biblique des derniers gestes $235 \mathrm{n} 18$

L'Empreinte à Crusoé 235n 18

L'Intraitable Beauté du monde [with Glissant, Édouard] 235n19

Le Papillon et la lumière 235n18
Charles-Wurtz, Ludmila

'La Poésie saxifrage' 64, 66-7

Chartier, Denis

'Littérature \& écologie' [with Blanc, Nathalie; Pughe, Thomas] see Blanc, Nathalie

Chavigny, Jean-Aimé de

La Premiere Face du Ianus François 27-30, 31, 39

Chelebourg, Christian

Les Écofictions 216

Chevignard, Bernard

'Jean-Aimé de Chavigny' 27n7

Chevillard, Éric 233

'Éric Chevillard' [with Cerquiglini, Blanche] see Cerquiglini, Blanche

'L'Humour du désastre' 224

Sans l'orang-outan 218-27

Cixous, Hélène 264

Clark, Timothy J.

The Painting of Modern Life 92-3

Claudel, Paul 145

Clés

'Michel Serres' [with Serres, Michel] see Serres, Michel

Collins, Desmond

'The Origins of Art' [with Onians, John] 186

Collot, Michel 265

Paysage et poésie 102

Pour une géographie littéraire 262

'Pour une géographie littéraire' 262

Commedia dell'arte

Harlequin 169

Pierrot 169

Comte, Auguste

Synthèse subjective $163,164 \mathrm{n} 32$, 165

Conley, Verena A.

Ecopolitics 264-5

Spatial Ecologies 265 
Connor, Steven K.

'Play Grounds' 160

Cornulier, Benoît de

De la métrique à

l'interprétation 111-12

Courbet, Gustave

L'Atelier du peintre 85

L'Origine du monde 184-6, 199n8

Les Demoiselles des bords de la

Seine 81, 92

Cousteau, Jacques-Yves 195

Le Monde du silence 14

Cusset, François

French Theory 260

Cyprian

De douze manieres d'abus [trans. by Morel, Fédéric] 30-1, 39

D

D'Angoulême, Henri 30

DalMolin, Eliane

'Editors' Introduction' [with Célestin, Roger; Dambre, Marc; Golsan, Richard J.] see Célestin, Roger

Dambre, Marc

'Editors' Introduction' [with Célestin, Roger; DalMolin, Eliane; Golsan, Richard J.] see Célestin, Roger

Darrieussecq, Marie 233, 265

Bref séjour chez les vivants 266

'Entretien réalisé par Becky Miller et Martha Holmes en décembre 2001' [with Miller, Becky; Holmes, Martha] 267

'Je est unE autre' 266

Le Pays 266

Darwin, Charles

De l'origine des espèces [trans. by Royer, Clémence-Auguste] 83, 86
The Origin of Species $66,77,83$, 85, 89

De Boever, Arne

“'Technical Mentality” Revisited' [with Massumi, Brian; Murray, Alex; Roffe, Jon] see Massumi, Brian

De Vriese, Hannes

'Écritures antillaises entre géopoétique et écopoétique' 233

Debray, Jules Régis

'Êtes-vous démocrate ou républicain?' 168n43

Déclaration des droits de l'homme et du citoyen 147

Defoe, Daniel Robinson Crusoe 238

Deguy, Michel 233

Deharme, Lise 143

Delachaux \& Niestlé 243

Deleuze, Gilles 260

Francis Bacon 86, 91-2

Kafka [with Guattari, Félix] 86, 87

'Postface' 189

Della Rocca de Vergalo, Nicanor A. Poëtique nouvelle 132-3

Derrida, Jacques 260

L'Animal que donc je suis 82, $183 \mathrm{n} 25$

Desblache, Lucile 'Introduction' $11 \mathrm{n} 6$

Descartes, René 85, 140, 146, 257, 262, 266

Discours de la méthode 183n25

Desert Fathers [Pères du désert] 242-3

Dillard, Annie 232, 261

Dioscures [Castor and Pollux] 189

Dissanayake, Ellen

Homo Aestheticus 90

Donne, John 181

Dorst, Jean 255 
Doward, Jamie

'Hawks, Butterflies, Coasts and

Footpaths' 235n20

Dowling, David

'Fraught Ecstasy' 246

Drouin, Jean-Marc

L'Écologie et son histoire $62 \mathrm{n} 4$

Dubus, Édouard

'Rythmes pittoresques, par Marie

Krysinska' 121

Dumont, René 255

Dupâquier, Jacques

Histoire de la population française $35 \mathrm{n} 25$

During, Élie

'Bruno Latour' [with Jeanpierre,

Laurent; Latour, Bruno] see Latour, Bruno

E

Egan, Gabriel

Green Shakespeare 26n2

Eire, Carlos M. N.

War Against the Idols 26n4

Eliade, Mircea

Forgerons et alchimistes 180-1, 186

Emerson, Ralph Waldo 191

'Emperor of the French'

Napoléon I 178n9

Napoléon III 62

Emporis

'High-Rise Buildings in SaintOuen' 94

Estok, Simon C.

'Theorizing in a Space of Ambivalent Openness' 18n15

F

Feder, Helena

'The Critical Relevance of the Critique of Rationalism' $15 \mathrm{n} 10$
Ferney, Alice

"Je rends hommage aux éco-terroristes"' [with Thibaud, Chloé] 234

Le Règne du vivant 234

Ferry, Luc

A Brief History of Thought 254n 4

Le Nouvel Ordre écologique [The

New Ecological Order] 178n8,

233-4, 238, 253-5

Finch-Race, Daniel A. 56n30

'Ecopoetic Ruminations in Baudelaire' 11n5

'Ecosensitivity in Rimbaud' 11n4

'Editorial' [with Weber, Julien]

$11 \mathrm{n} 6,84,236 \mathrm{n} 22,247 \mathrm{n} 37$

Firmus 51

Flahault, François

Le Crépuscule de Prométhée 178n9, 179 n 11

Fontenay, Élisabeth de

Le Silence des bêtes 182

Ford, Caroline

'Nature, Culture and Conservation in France and her Colonies 1840-1940' 258-9

Forrest, Jennifer

'Paris à Rebours' 84, 86n21

Foucault, Michel 260

Fourier, Charles 70n30

Freccero, Carla

'Queer Times' 16n12

French publishers with an environ-

mental specialisation

Gallmeister 232

Seuil 232

Wildproject 232

Freud, Sigmund 160

Frisch, Andrea

The Invention of the Eyewitness 45n6 
Froumenteau, Nicolas

Le Secret des finances de

France 31-3, 34-6, 37, 39

G

Gaard, Greta

Ecofeminism 144n25

Gaillard, Françoise

'Allégorie d'un fantasme fin de siècle' 183 n24, 184

Galey, Matthieu

Les Yeux ouverts [with Yourcenar, Marguerite] see Yourcenar, Marguerite

Gallican Church

La Poligamie sacree 33

Garcin, Jérôme

'Un entretien avec Michel Houellebecq' [with Houellebecq, Michel] 226

Garrard, Greg

Ecocriticism 267

Teaching Ecocriticism and Green Cultural Studies 138

'The Function of Criticism' [with Bartosch, Roman] see Bartosch, Roman

The Oxford Handbook of Ecocriticism 10n2

Gascar, Pierre 233

Gatta, John

Making Nature Sacred 241, 242

Gaudé, Laurent

Ouragan 219

Gaudon, Jean

Le Temps de la contemplation $65 \mathrm{n} 20$

Gentillet, Innocent

Contre Nicolas Machiavel 30

Gille, Philippe

'Revue bibliographique' 132
Gilligan, Carol

In a Different Voice 144

Gilmont, Jean-François

GLN 15-16 26n3

Giono, Jean 232

Giorgione

Tempesta 199, 200

Glissant, Édouard

L'Intraitable Beauté du monde

[with Chamoiseau, Patrick] see

Chamoiseau, Patrick

Goethe, Johann W. von 68n28, 176, 182-3

Gollain, Françoise

'André Gorz' 11n5

Golsan, Richard J.

'Editors' Introduction' [with Cé-

lestin, Roger; DalMolin, Eliane;

Dambre, Marc] see Célestin,

Roger

Goodbody, Axel

Ecocritical Theory [with Rigby,

Kate] 10n2

Goscinny, René

Astérix [with Uderzo, Albert] 14

Goslar, Michèle

'Marguerite Yourcenar y la protección de la naturaleza' 138

Goul, Pauline

“Et voylà l'ouvrage gasté" $44 n 3$

Goya, Francisco de

Men Fighting with Sticks 83

Gracq, Julien 232

Granger, Michel

'Introduction' [with Pughe, Tom]

see Pughe, Thomas

Greek mythology

Aphrodite [Vénus] 127, 184, 189,

191

Eros 175, 187, 188, 189, 190

Gaia 106, 165-6 
Leda 189

Prometheus 176, 178n9, 179

Grinevald, Jacques

'La Thèse de Lynn White, Jr (1966)' 29n12

Grove, Richard H.

Green Imperialism 26n2

Guattari, Félix 196, 200, 209, 210, 260, 265

Chaosmose [Chaosmosis] 207-8

Kafka [with Deleuze, Gilles] see

Deleuze, Gilles

Les Trois Écologies 257, 266-7

Qu'est-ce que lécosophie? 207

Guest, Bertrand

'L'Essai, forme-sens de l'écologie littéraire naissante?' $261 \mathrm{n} 31$

Guichard, Thierry

'Le Monde réapproprié 178n9, $185 \mathrm{n} 31$

Gunther, Scott

'Alors, Are We “Queer” Yet?' 260n26

H

Haag, Émile

La France protestante [with Haag,

Eugène] see Haag, Eugène

Haag, Eugène

La France protestante [with Haag, Émilie] 32n19

Haeckel, Ernst H. P. A.

Generelle Morphologie der Organismen $13,62 \mathrm{n} 4,84,158$

Hainard, Robert

Recours à la 'nature sauvage' 241

Harris, Paul A.

'The Itinerant Theorist' 155

Harrow, Susan

'Thérèse Raquin' 85

Haussmann, Georges-Eugène 100, 101

Hegel, Georg W. F. 66
Heidegger, Martin

'Die Frage nach der Technik' 179n10

'The Question Concerning Technology' [trans. by Krell, David F.] $179 \mathrm{n} 10$

Heinz [H. J. Heinz Company] 237, 239, 245

Heise, Ursula K.

'The Hitchhiker's Guide to Ecocriticism' 10n2, 233n11

Hetzel, Pierre-Jules

Correspondance [with Hugo, Victor M.] see Hugo, Victor M.

Hitt, Christopher

'Toward an Ecological Sublime' 247

Hoffmann, Richard C.

An Environmental History of Medieval Europe 26n2, 29n12

Holmes, Martha

'Entretien réalisé par Becky Miller et Martha Holmes en décembre 2001' [with Darrieussecq, Marie; Miller, Becky] see Darrieussecq, Marie

Houellebecq, Michel 232

La Possibilité d'une île 218-27

'Un entretien avec Michel Houellebecq' [with Garcin, Jérôme] see Garcin, Jérôme

Howard, Luke

Essay on the Modification of Clouds 176

Hugo, Adèle [née Foucher, 1803-68] 62 Hugo, Adèle [1830-1915] 62

Hugo, Léopoldine 67

Hugo, Victor M. 99, 120

Correspondance 62, 63, 64

Correspondance [with Hetzel,

Pierre-Jules] 61, 63n10, 66

Dieu 66n22

Les Châtiments 62n5 
Les Contemplations $61-74,77$

Les Misérables 62,73-5,76-8

Les Rayons et les ombres $62 \mathrm{n} 5$

Les Travailleurs de la mer 65

Huillet, Danièle 198n5

Humboldt, Alexander von 261n31

I

Irigaray, Luce $264-5$

J

Jaccottet, Philippe 233

James, William

Essays in Radical Empiricism 206

Jeangène Vilmer, Jean-Baptiste

Éthique animale $144 \mathrm{n} 24$

Jeanpierre, Laurent

'Bruno Latour' [with During, Élie;

Latour, Bruno] see Latour,

Bruno

Jonas, Hans

Das Prinzip Verantwortung 219

Josephson, Matthew

Zola and His Time 90-1

K

Kahn, Gustave 118

Palais nomades 118

Kant, Immanuel 253

Karr, Alphonse 63

Keats, John

'To Autumn' 75-6

Kermode, Frank

The Sense of an Ending 217, 218

Kerridge, Richard

'Ecocriticism and the Mission of "English" 137

'Introduction' 149

King, Ynestra

'The Ecology of Feminism and the Feminism of Ecology' 182
'King of France'

Charles IX 30

François I [Francis I] 43, 90

Henri II 35

Henri III 27, 30, 31, 33, 34, 36

Henri IV 28, 29, 31

Louis XII 36

Kohlberg, Lawrence 144

Kolodny, Annette

The Lay of the Land 182

Krell, David F.

'The Question Concerning Technology' [trans. of Heidegger, Martin] see

Heidegger, Martin

Krysinska, Marie

Intermèdes 120-1, 122

Joies errantes 119

Rythmes pittoresques 118-20,121,

$$
\text { 122-33 }
$$

L

La Fayette, Madame de La Princesse de Clèves 14

La Fontaine, Jean de Fables 14

Lafon, Marie-Hélène 233, 265

L'Annonce 268-9

Les Derniers Indiens 268-9

Les Pays 268-9

Laforgue, Jules

Derniers vers 118

Lamarck, Jean-Baptiste 177n5

Lamartine, Alphonse de

Méditations poétiques 117

Lang, Abigail

'De la poetry reading à la lecture publique' 115

Lapp, John

Zola before the RougonMacquart 81-2, 85 
Larousse, Pierre

Grand dictionnaire universel $d u$ XIXe siècle 121-2

Larrère, Catherine

'Éthiques de l'environnement' $261 \mathrm{n} 29$

Les Philosophies de l'environnement 217n5, 254

Latour, Bruno 254

'Agency at the Time of the Anthropocene' 264

'Arrachement ou attachement à la nature?' $178 \mathrm{n} 8$

'Bruno Latour' [with During, Élie; Jeanpierre, Laurent] 19

Éclaircissements [with Serres, Michel] see Serres, Michel

Face à Gaïa 165n39

'Facing Gaia' 165

Nous navons jamais été modernes $168 \mathrm{n} 43,257$

Politiques de la nature 217n5

'The Puzzling Face of a Secular Gaia' 165-6

Lawrence, David H. R.

Lady Chatterley's Lover 240

Le Goff, Jean-Pierre

La Fin du village 268

Le Loup, Remacle

Les Délices du pays de Liège 142

Le Parisien 242-3

Lee, Daryl P.

'Rimbaud's Ruin of French Verse' 102-3

Leibniz, Gottfried W. 159n26

Lejosne-Guigon, Renaud

'Consommer le réel' 104

Leménager, Grégoire

'Houellebecq' 227n26

Lestringant, Frank

“L'Archipel de la Manche"” 64-5
Lethbridge, Robert

'Zola, Manet and Thérèse Raquin' 89,90

Lévi-Strauss, Claude 139, 264

'L'Etnòleg enfront de les identitats nacionals' 239

Lévy, Bernard-Henri

American Talk of the Death of French Culture Says More about Them than about Us' 258n18

Lévy, Sydney

'Introduction' 155

Ligny, Jean-Marc 218n11

Lopez, Barry 232

Lorraine-Vaudémont, Louise de 31, 36

Lovelock, James

The Ages of Gaia 165

Lucretius [Lucrèce]

De rerum natura [On the Nature of Things] 178n8, 191, 196, 200-3, 204, 205-6, 208, 210

On the Nature of Things [trans. by Smith, Martin Ferguson] 205

Luke, Timothy W.

Ecocritique 256n10

Lunn-Rockliffe, Katherine

'Humanity's Struggle with Nature in Victor Hugo' 66

M

Machiavel, Nicolas [Niccolò Machiavelli]

Le Prince [trans. by Gohory, Jacques] 30

Mackenzie, Louisa

French Thinking about Animals [with Posthumus, Stephanie] 85

'It's a Queer Thing' 14

'Reading Latour Outside' [with

Posthumus, Stephanie] 11n4 
Index

Majer O'Sickey, Ingeborg

'Introduction' 139n4

Malingre, Mathieu

Noelz nouveaulx 25

Mallarmé, Stéphane 116, 126

'Un coup de dés' 117, 128

Malthusianism 238

Manet, Édouard

Déjeuner sur l'herbe 81, 92

Olympia 86, 89

Manichaeism 237

Marceau, Marcel 258

Marcel, Étienne 37

Marland, Pippa

'Ecocriticism' 116n3, 117, 133

Massumi, Brian

“'Technical Mentality” Revisited'

[with De Boever, Arne; Murray,

Alex; Roffe, Jon] 207

Maurras, Charles

'Rythmes pittoresques, par Marie

Krysinska' 133

McCarthy, Cormac

The Road 217

McEwan, Ian

'The Day of Judgment' 218n9

McHugh, Susan

Animal Stories 82, 85n16

McLaughlin, Emily

'The Practice of Writing and the

Practice of Living' 233n7

McLean, Steven

"'The Golden Fly" 83n6

Melville, Herman 66n23

Ménager, Daniel

'Montaigne et la magnificence' $5 \ln 16$

Menanteau, Guilhem

'Éric Chevillard, Sans l'orang-outan' 224

Mendès, Catulle

Le Mouvement poétique français de 1867 à 1900 132-3
Merchant, Carolyn

The Death of Nature 143, 181-2

Meurice, Paul 64

Mieck, Ilja

'Reflections on a Typology of Historical Pollution' 87n22

Miller, Becky

'Entretien réalisé par Becky Miller et Martha Holmes en décembre 2001' [with Darrieussecq, Marie; Holmes, Martha] see Darrieussecq, Marie

Milton, John

Paradise Lost 182

Mingarelli, Hubert 233

Mistral, Frédéric 195

Monet, Claude 85

Montaigne, Michel de

Les Essais 44-56

Montand, Nicolas de

Le Miroir des François 31-3, 36-9

Montchrestien, Antoine de

Traicté de l'oeconomie politique $36 \mathrm{n} 29$

Moore, Jason W.

'The Modern World-System as Environmental History?' 26n2

Moréas, Jean 118

Morel, Bénédict A.

Traité des dégénérescences physiques, intellectuelles, et morales de l'espèce humaine 83n5

Morel, Fédéric

De douze manieres d'abus [trans. of Cyprian] see Cyprian

Morin, Edgar 255

Morrison, Donald

'In Search of Lost Time' 258

Morton, Timothy

Ecology without Nature 19n16, 256

Moscovici, Serge 255 
Moser, Keith

'The Eco-Philosophy of Michel Serres and J. M. G. Le Clézio' $11 \mathrm{n} 4$

Murat, Michel L'Art de Rimbaud 109

Le Vers libre 118, 127, 128

Murphy, Steve

Stratégies de Rimbaud 110

Murray, Alex

“Technical Mentality” Revisited' [with Massumi, Brian; De Boever, Arne; Roffe, Jon] see Massumi, Brian

$\mathbf{N}$

Næss, Arne 238

Nazism 233

Nelson, John W.

'The Apocalyptic Vision in American Popular Culture' 218

Neyrat, Cyril

'Entretien avec Jean-Claude

Rousseau' [with Rousseau, JeanClaude] 196n2, 198n3

Nochlin, Linda

'Courbet's L'Origine du monde' 186

Nodier, Charles $68 \mathrm{n} 28$

Nolan, Christopher

Interstellar 217

Nostredame, Michel de [Nostradamus]

Prophéties [Centuries] 27, 28-9

O

Olivétan, Pierre Robert

Leviticus [trans. of Bible] see Bible

Onians, John

'The Origins of Art' [with Collins,

Desmond] see Collins, Desmond Ormesson, Jean d' 139
$\mathbf{P}$

Padilla, Andrea

Marguerite Yourcenar y la ecología [with Torres, Vicente] 138

Parfait, Noël 63,66

Pasteur, Louis

Les Microbes organisés 165

Petit-Poucet [Little Thumb] 108, 109

Petrarch [Francesco Petrarca] 195

Pettegree, Andrew

French Vernacular Books [with

Walsby, Malcolm; Wilkinson,

Alexander S.] 26n3

Picot, Georges

Histoire des États Généraux 35n26

Piel, Jean

La Part maudite; La Notion de dépense [ed. of Bataille, Georges] see Bataille, Georges

Pinkus, Karen

'The Risks of Sustainability' 56

Piranesi, Giovanni Battista 142

Pissarro, Camille 92

Plato

Symposium 187

Pleynet, Marcelin

'Poésie oui' 199

Poignault, Rémy

'Ensayos y meditaciones' 147-8

Poovey, Mary

A History of the Modern Fact 36

Posthumus, Stephanie 48n13,56n30,

$162 \mathrm{n} 29$

'Eco- and Geo- Approaches in

French and Francophone

Literary Studies' [with Bouvet,

Rachel] see Bouvet, Rachel

'État des lieux de la pensée écocri-

tique française' $216 \mathrm{n} 3$

French 'Écocritique' 10, 265n45 
French Thinking about Animals [with Mackenzie, Louisa] see Mackenzie, Louisa

'L'Habiter écologique et l'imaginaire paysan chez MarieHélène Lafon et Michel Serres' 233n9, 236, 247n37

'La Nature et l'écologie chez LéviStrauss, Tournier, Serres' 155

'Penser l'imagination environnementale française sous le signe de la différence' 216 n3

'Reading Environment(s)' [with Sinclair, Stefan] 11n5

'Reading Latour Outside' [with Mackenzie, Louisa] see Mackenzie, Louisa

'Translating Ecocriticism' 156, $257 \mathrm{n} 12$

'Vers une écocritique française' 156-7, 257n12

Pouvoirs

'Entretien avec Michel Serres' [with Serres, Michel] see Serres, Michel Prasad, Monica

'Why Is France So French?' 257n16 Prigogine, Ilya 264

Proust, Marcel

À la recherche du temps perdu 177n6 Prudhomme, Sully 121

Puff, Jean-François

'La Voix off de soi-même' 116 Pughe, Thomas

'Introduction' [with Granger, Michel] 261

'Littérature \& écologie' [with Blanc, Nathalie; Chartier, Denis] see Blanc, Nathalie

Puleo, Alicia H.

Ecofeminismo para otro mundo posible $144 \mathrm{n} 25$
Q

Quandt, Karen F.

"Foliis ac frondibus" 78n42

$\mathbf{R}$

Racevskis, Roland

'Cyrano's Posthuman Moon' 15n10

Rancière, Jacques

La Parole muette 100-1

Ravindranathan, Thangam

'Un hérisson peut toujours arriver' 233n9

Reclus, Élisée 261n31

Revue critique de fixxion française contemporaine 232, 235

Richards, John F.

The Unending Frontier 26n2

Rigby, Kate

'Earth, World, Text' 17

Ecocritical Theory [with Goodbody, Axel] see Goodbody, Axel

Rimbaud, Arthur

Illuminations 118

Letter to Paul Demeny [15

May 1871] 74

Poésies 99-113, 126

Robb, Graham

Victor Hugo 64

Roffe, Jon

“'Technical Mentality” Revisited' [with Massumi, Brian; De

Boever, Arne; Murray, Alex] see Massumi, Brian

Rosny, J.-H.

'Préface' 118

Roubaud, Jacques

'Poésie et oralité' 115-16

Rousseau, Jean-Claude

'Entretien avec Jean-Claude Rousseau' [with Neyrat, Cyril] see Neyrat, Cyril 
'Entretiens avec Jean-Claude Rousseau' [with Yon, David] see Yon, David

La Vallée close 196-8, 199-203, 206-10

Rousseau, Jean-Jacques 68n28, 87, 160

Les Rêveries du promeneur solitaire 191

Royer, Clémence-Auguste

De l'origine des espèces [trans. of Darwin, Charles] see Darwin, Charles

Royet-Journoud, Claude 115 Rufin, Jean-Christophe

Le Parfum d'Adam 234, 238

$S$

Sade, Donatien Alphonse François de Justine 186

Saint-Simon, Henri de 70n30 Sanz, Teófilo

'Féminiser le masculin ou renier la féminité" 145 n 27

'L'Engagement écologique de Marguerite Yourcenar' 140n7

Sauvagnargues, Anne

'Crystals and Membranes' 204

Savigneau, Josyane

Marguerite Yourcenar 139n4

Scarry, Elaine

On Beauty and Being Just 208, 209

Schaeffer, Jean-Marie

Petite écologie des études littéraires 261

Schaffner, Franklin J.

Planet of the Apes 217

Schoentjes, Pierre

Ce qui a lieu 216n4, 231-2, 243-4, 263n39

'Texte de la nature et nature du texte' $232 \mathrm{n} 4$
Scholl, Aurélien

'Chronique parisienne' 132

Schrader, Franz 139

Scott, Clive

'Translating the Nineteenth Century' $117,126,131$

Serres, Michel 178n8, 254, 264, 265, 269

Biogée 157n23, 160, 161, 166

Détachement 268

Éclaircissements [with Latour, Bruno] 164,166

'Entretien avec Michel Serres' [with Pouvoirs] 157n23, 160

Habiter 157n23, 163

Hermès $V$ [Le Passage du NordOuest] 270

Hominescence 17, 155-6, 164, 255-6, 268

L'Incandescent 163, 169

La Guerre mondiale 157n23, 167, 169-70

La Naissance de la physique dans le texte de Lucrèce 205, 206

Le Contrat naturel [The Natural Contract] 61, 65n19, 83-4, 155-7, 163, 177n6, 217n5, 255-6, 257

Le Grand Récit de l'Univers 156

Le Mal propre [Malfeasance] 154, 158-62, 168

Le Parasite 154, 159n24, 164n32

'Le Temps humain' 164

Les Cinq Sens 268

'Michel Serres' [with Clés] 157n23

Pantopie 153, 157-8, 159, 160, 163, $164,165,167,168$

'Peut-on dire encore le pouvoir spirituel?' 268

Rameaux 159, 162, 164

Récits d'humanisme 163

Rome 159n24

Statues 159n24 
Temps des crises 149

'Un entretien avec Michel Serres' [with Abraham, Luc] 154

Shelley, Mary Wollstonecraft 176

Shelley, Percy Bysshe

'The Cloud' 176

Shideler, Ross

Questioning the Father 83

Sibona, Bruno

'Les Tritons de Théophile' 15n10

Simon, Anne

'Animality and Contemporary French Literary Studies' 93-4, 260n 27

Simondon, Gilbert 196, 206, 207, 208, 209, 210

Imagination et invention (1965-66) 204

L'Individuation à la lumière des notions de forme et d'information 198-9, 201, 203, 205

Sinclair, Stefan

'Reading Environment(s)' [with Posthumus, Stephanie] see Posthumus, Stephanie

Singer, Peter

Animal Liberation 146n29

Practical Ethics 146n29

Smith, Martin Ferguson

On the Nature of Things [trans. of Lucretius] see Lucretius

Snyder, Gary 232

Soupault, Philippe

Les Champs magnétiques [with

Breton, André] see Breton, André

Spenser, Edmund

The Faerie Queene 181-2

Spivak, Gayatri C.

Death of a Discipline 259
St Clair, Robert A.

'Le Moderne absolu?' 102

Stalinism 233

Stauffer, Robert C.

'Haeckel, Darwin, and Ecology' $84 \mathrm{n} 12$

Stengers, Isabelle 264

Stevenson, Robert L.

Strange Case of Dr Jekyll and Mr Hyde 269

Stoekl, Allan

Bataille's Peak 52, 56

Straub, Jean-Marie 198n5

Subcommission on Quaternary Stra-

tigraphy

'Working Group on the "Anthropocene" 164

Suberchicot, Alain

Littérature américaine et écologie 232n 5,264

Littérature et environnement 10 , 216n4, 232n5, 264

Sullivan, Marnie

Ecocritical Approaches to Literature in French [with Boudreau, Douglas] see Boudreau, Douglas

T

Taine, Hippolyte 85

Takenaka, Koji

'Montaigne et l'économie royale' $44 \mathrm{n} 5$

Tesson, Sylvain

Dans les forêts de Sibérie 235-47

Theocritus 68

Thibaud, Chloé

"Je rends hommage aux éco-terroristes"' [with Ferney, Alice] see Ferney, Alice

Thomas, Keith

Man and the Natural World 26n2 
Thoreau, Henry David 66n23, 191, 232, 261

Walden 235, 236-7, 245, 246

Torres, Vicente

Marguerite Yourcenar y la ecología [with Padilla, Andrea] see Padilla, Andrea

Tournier, Michel

Les Météores 177n6, 190

Vendredi ou les limbes du Pacifique 188, 189, 190

Trassard, Jean-Loup 247

'Arrêtez le massacre' 234n17

L'Homme des haies 234n17

Trinity College [Cambridge - England]

'French Ecocriticism' 19

Tuan, Yi-Fu

Space and Place 101

Topophilia 236-7

Turner, Joseph Mallord William 176

U

Uderzo, Albert

Astérix [with Goscinny, René] see Goscinny, René

UNESCO [United Nations Educational, Scientific and Cultural Organization]

Déclaration universelle des droits de l'animal 147

Université d'Angers

'Écocritique' $12 \mathrm{n} 7$

'ÉcoLitt' 12n7, 217

Université de Perpignan

'Lieux d'enchantement' 12n7

V

Valéry, Paul 116

Van Hasselt, André 62

Verlaine, Paul

Romances sans paroles 126,128
Vermeer, Johannes 197, 199

Verne, Jules G. 178n9

Versoris, Pierre de 37

Viard, Jean

Le Tiers Espace 258

Vignes, Sylvie

'Hubert Mingarelli' 233n9

Virgil 140

Volodine, Antoine 227

Des anges mineurs 224n22

Dondog 224n22

Voltaire

Candide 14

Von Hochheim, Eckhart 148

W

Wagner, W. Richard

Parsifal 142

Wallerstein, Immanuel

The Modern World-System 26n2

Walsby, Malcolm

French Vernacular Books [with

Pettegree, Andrew; Wilkinson,

Alexander S.] see Pettegree,

Andrew

Wandel, Lee P.

Voracious Idols and Violent

Hands 26n 4

Warren, Karen

Ecological Feminist Philoso-

phies $144 \mathrm{n} 25$

Waters, Colin N.

'The Anthropocene Is Functionally and Stratigraphically

Distinct from the Holocene' 164 n37

Watson, Paul F. 234

Weber, Julien

'Editorial' [with Finch-Race, Daniel

A.] see Finch-Race, Daniel A.

Westphal, Bertrand

La Géocritique 262 
Whidden, Seth

'Sur la "supercherie" de Marie Krysinska' 127

White, Kenneth

'Le Grand Champ de la géopoétique' 262-3

White Jr, Lynn T.

'The Historical Roots of Our Ecologic Crisis' 29, 39

Whiteside, Kerry H.

Divided Natures 255

Wilkinson, Alexander S.

French Vernacular Books [with

Pettegree, Andrew; Walsby,

Malcolm] see Pettegree, Andrew

Wordsworth, William

'I Wandered Lonely as a Cloud' 176

WCED [World Commission on Environment and Development]

Our Common Future 51

Worster, David

Nature's Economy 66n23

Y

Yon, David

'Entretiens avec Jean-Claude

Rousseau' [with Rousseau, Jean-

Claude] 203, 206, 208
Yourcenar, Marguerite 11-12, 137-8

Archives du Nord 142-3

En pèlerin et en étranger 148

L'Euvre au noir 143

La Petite Sirène 141

La Voix des choses 148

'Le Droit à la qualité de

l'environnement' 139-40

Le Labyrinthe du monde 141

Le Temps, ce grand sculpteur 146

Les Yeux ouverts [with Galey,

Matthieu] 139, 141, 143, 144, 148

Lettres à ses amis et quelques autres 143

Sources II $147-8$

Souvenirs pieux 141-2

Un homme obscur 138, 140-1, 143,

$145-6,147,148-9$

Z

Zola, Émile

Le Roman expérimental 85

'M. Manet' 89

Thérèse Raquin 81-94

Zorach, Rebecca

Blood, Milk, Ink, Gold 44

Žukauskaitè, Audronè

'Ethics between Particularity and

Universality' $87 \mathrm{n} 23$ 